Volume 10, Issue 6, November-December 2019, pp. 99-104, Article ID: IJM_10_06_010

Available online at http://iaeme.com/Home/issue/IJM?Volume $=10 \&$ Issue $=6$

Journal Impact Factor (2019): 9.6780 (Calculated by GISI) www.jifactor.com

ISSN Print: 0976-6502 and ISSN Online: 0976-6510

C IAEME Publication

\title{
PSYCHOLOGICAL WELLBEING INTENDED FOR HEALTHY LONGEVITY
}

\author{
Dr. M.P. Agathiyar \\ Ph.D. Scholar, Department of Economics, \\ VISTAS (Vels University), Pallavaram, Chennai, India \\ Dr. S.N. Sugumar \\ Head, Department of Economics, \\ VISTAS (Vels University), Pallavaram, Chennai, India
}

\begin{abstract}
Human body has multidimensional ability to perceive consciousness and has infinite capacity to change, heal and renew by itself which is called rejuvenation. The estimation of Life Expectancy based on data from World Health Organization (WHO) and World Development Indicators (WDI) 2015, ranked 145/187 for India reflects poor life expectancy. Psychological wellbeing and emotional regulations are linked with better health and prevent illness physiologically. The concept of "Kaayakarpam" healthy longevity research from the siddha philosophy counterparts that longevity potential includes observation of certain lifestyle that help to prevent psychosomatic disease as mentioned in "Theraiyar Pini Anugaa Vidhi" as it makes human body resilient naturally.
\end{abstract}

Keywords: psychological wellbeing, longevity, emotional regulation, kayakarpam

Cite this Article: Dr. M.P. Agathiyar and Dr. S.N. Sugumar, Psychological Wellbeing Intended for Healthy Longevity, International Journal of Management (IJM), 10 (6), 2019, pp. 99-104.

http://iaeme.com/Home/issue/IJM?Volume=10\&Issue $=6$

\section{INTRODUCTION}

Human body has multidimensional ability to perceive consciousness and has infinite capacity to change, heal and renew by itself which is called rejuvenation. During 2015-16, NIMHANS has selected 12 states across India and conducted the National Mental Health Survey (NMHS) reported that $10 \%$ of the Indian population suffered from minor affective disorder such as anxiety, stress and depression which affects health and longevity in the population. The concept of "Kaayakarpam" healthy longevity research from the siddha philosophy counterparts that longevity potential includes observation of certain rules that help to prevent psychosomatic disease as mentioned in "Theraiyar Pini Anugaa Vidhi" as it makes human body resilient naturally. [1] 


\section{HEALTH STATISTICS OF INDIA}

In India, Civil Registration System (CRS) envisages compilation of continuous series of health related vital events along with birth and death registration. The record of public health administration based on its data-cum core vital statistics controlled by the Registrar General of India. There are about two lakhs reporting units in India, under the control of Chief Registrar of Births and Deaths who is the authority to implement the Registration of Births and Deaths (RBD) Act, 1969. The Central Bureau of Health Intelligence (CBHI), State Directorates of Economics and Statistics in some states and the Rural Health Division of director general of health services (DGHS) collect and publish Rural Health Statistics. Crude Birth rate declined from 22.1 in 2010 to 20.2 in 2017 per 1000 population, while the death rate declined from 7.2 in 2010 to 6.3 in 2017. The Sample Registration System of 2017 also shows that the Total Fertility Rate (TFR) - the average number of children that will be born to a woman, has also declined to 2.43. TFR is declining rapidly in Delhi, West Bengal and Tamil Nadu also in the rest of the states in India. [2]

\section{HAPPINESS INDEX}

Adam Smith's economic strategy on Wealth of Nations made remarkable affluence to drive many nations to astounding economic growth. But inadequacy in maximizing happiness of the citizens leads to construct the term "Gross National Happiness - GNH", developed in 1972. Jigme Singye Wangchuck opened the idea that GNP is more important rather than GDP was adopted by UNO and sixty eight countries endorsed the same. Carol Graham also emphasis that a person who spends time with family members, relatives and friends besides focusses on little things can be happier and they would have larger GNH. The World Happiness Index constructed on the basis of good governance, GDP per capita, healthy life expectancy, social freedom, social support, generosity, natural environment and corruption less governance. The World Happiness Index 2019 for 156 countries, has ranked India in $140^{\text {th }}$ position whereas it was $133^{\text {rd }}$ in $2018,122^{\text {nd }}$ in $2017,118^{\text {th }}$ in 2016 , and 117 th in 2015 . Finland topped the first position, replaced Norway to be the world's happiest country, which was ranked $5^{\text {th }}$ in 2016 . Among the SAARC countries, in contrast Pakistan was ranked $67^{\text {th }}$, China at $73^{\text {rd }}$ while Bhutan was ranked at $95^{\text {th }}$. Nepal has been placed at $100^{\text {th }}$ place and Sri Lanka at $130^{\text {th }}$ place. The happiness index for Bangladesh was rated at $125^{\text {th }}$ position. [3]

The estimation of Life Expectancy based on data from World Health Organization (WHO) and World Development Indicators (WDI) 2015, (ranked 145/187 for India) reflect poor life expectancy. India was ranked at $111^{\text {th }}$ in 2013 and currently despite of rich amenities, the overall happiness has thrown down lower to some of its bordering nations. Research across thirty three different countries revealed that individuals who obtained self-fulfillment, personal development and strong social interaction are significantly linked to individual happiness and were happier than others. In India, there is an increasing trend in affective disorder and Lifestyle Diseases. World Health Organization, in its study 2011, revealed that $9 \%$ of the Indians were suffering from depression

\section{PSYCHOLOGICAL FACTORS}

Psychological factors are the components of personality and mental state of an individual that limit or enhance the action to seek satisfaction. The attitudes or behaviors of an individual have a negative effect on health, which differ among women and men. Some of the psychological factors that influences longevity were,

TEMPERAMENT: Scientific evidence indicates that three negative emotions such as anger, anxiety, and depression may cause coronary heart disease.[4] Neuroendocrine and cardiovascular response increase testosterone level with decreased cortisol in systemic 
circulation as a response to anger or short temperament. Short temper is a personality trait that may increases uncontrolled emotional irritability which could also provoke various illness.

LONELINESS AND RESERVED: Lack of spousal support and disability among males with poor self-rated health lead to higher Mortality in India.[5] Among elderly people, the loneliness feeling associated with age, health status, physical limitation were inversely correlated with residence. Human existence was portrayed as the sense of connectedness or relatedness, possibly be in the right place of family, culturally has an impact on psychological well-being positively.

DEPRESSIVE: The impact of depression on health which is a negative emotional state may occur indirectly through negative thinking and it is associated with health behaviors and health outcome. [6] Chronicity may also associated with reduced quality of life, lessens socio economic aspects and sometimes poor treatment outcomes.

PRIDE: Pride is a self-conscious emotion which has both positive aspect that promotes confidence and negative aspect often gets a bad resonance. It is a core moral emotion that vary with individual and ranges from mild to severe. Pride may lead to arrogance that trigger varied set of health risks associated with negative emotions.

\section{EMOTIONAL FACTORS}

Emotions are the way our body's biological response to feelings which has its effect on internal organs of the body. In Traditional Chinese Medicine joy, anger, grief, fear, pensiveness, sadness, and worry are the seven emotions and its imbalance cause diseases in human. The core problem in our country is funneled with negative thoughts and we tend to think that there so much negative with this country which is not true. Emotional competence involves an affluence around others emotions and determines the ability to express. Understanding some important emotions as typical is the core notion of emotional competence to lead healthy life successfully and they are,

RESILIENCE: Resilience is the capability to recover again from difficult situations effectively towards adaptation. The psychosocial resources of personal resilience, cognitive resilience and socio-economic resilience are linked to longevity. [7] The promotion of positive emotional evolvement, rooted in early life experiences and living conditions is necessary intervened to develop maximum resilience scores in individuals. Lower resilience scores may worsen disease condition, decreases the quality of life. Hence higher resilience can be significant factor in health outcome of the individual.

OPTIMISTIC: The attitude of positive thinking to wellbeing by guessing the best possible outcome in any situation of life, relying on the future conditions will work for the best. It is mostly emotion focused adaptive strategies, refraining any situation with acceptance by holding positive expectancies. Coping more adaptively with stress by optimistic approach that too develop stable characteristic in individuals and have beneficial effects on psychological and physical well-being. [8]

EXPRESSIVE: Revealing or talking about their feelings or thoughts with the close persons effectively. Great smiles, laughing, frowning, shouting, loud crying, expressive body act like jumping for joy and anything that communicates are all expressive. Conveying better emotional expressions can occur with or without self-awareness, in fact has powerful influence on health.

ACCEPTANCE: Acceptance is the course of emotion-regulation strategies, deliberately engaging with negative emotions. The attitude of accepting something is a response focused strategy allowing to experience without altering or suppressing it. This is an active process that enhance the understanding to engage in unpleasant situation or mitigate emotion towards 
mindfulness with more valued context in life. Cognitive functions that decline with ageing, then again is associated with increased acceptance.

ADAPTATION: A happy healthy adjustable individual can attain all dimensions of health. Adaptations that were made with life conditions can drive rhythmic response to stimuli. Adaptation to daily stress by the brain and nature of interventions involves neuroendocrine functions of hypothalamus connected with the pituitary gland. The ability of the brain and body to adapt to acute and chronic stress explicitly reflect both positive and negative aspect of aging by means of psychological perspective on health.

COMPASSIONATE: compassionate means the strong feeling of showing concern for other people or understanding the sufferings and wish to help them at the needy time. This is a very thoughtful positive emotion that drives the world functioning. The great Tamil poet Thiruvalluvar in his thirukural "Kannirkanikalam kannottam" emphasized through the worldview that kindhearted people's eyes are adorned by compassion for social significance. Those who possess the wealth of compassion were charmingly civilized to respect all living creatures to shower the loving care with empathetic fellow feeling attitude.

\section{PSYCHOLOGICAL AND EMOTIONAL WELLBEING FOR LONGEVITY}

The organs and tissues of human body are built by nearly 100 trillion cells, which begins as a single cell made of a nucleated mass of protoplasm enclosed within a membrane. The natural phase of the cell life includes growth, maturity and death were regulated by many factors same like the three great processes of God namely creation, preservation and destruction. Each cell in the body contain RNA, which is a molecular message made of about 300 proteins needed for life activities and are regulated by genes which forms the source of longevity. Cellular senescence happens through gene expression changes ultimately for self-preservation of organism by a process called autophagy. Every cell contains stored memory of times past and present that continues to shift and shape our lives and future. Psychological agony emanates from fear of future or recalling with retained worrisome memories of the past life. It has long been recognized in mainstream medicine the connection between our thoughts, mind, emotions and body. The unresolved mental factors, emotions include grief, anger, jealousy, hatred, guilt and shame are not allowed to percolate through our being but are suppressed and ignored. These emotional blocks can go up leading to physical symptoms which ultimately manifest as illness. Physical health influences psychological well-being among elderly people were measured by positive as well as negative affect and has strong association with behavioral aspects and better living. [9] The physical health and psychological well-being are also mediated by social wellbeing. Psychological wellbeing and emotions regulation are linked with better health and prevent illness physiologically. Both psychological wellbeing and emotional health are serious factors in determination of physical health of elderly human life.

\section{CONCEPT OF KAYAKARPAM}

Thirumandiram verily the seed of universal knowledge states that "lead me from ignorance to light, lead me from mortality to immortality, lead me to realization of truth", emphasis the conceptual goal of staying healthy without disease had sowed the knowledge of longevity. The human is a unification of body, mind and spirit with definite features nourished by golden inner light and is inseparable until death. [10] Nobody should suffer from any disease during their lifetime because healthy soul can evolve through a healthy body as comprehended by Sage Thirumoolar.

Siddhars learned the relationship of body with immortal soul also apprehended capacity of man to live without sickness and suffering. Siddhars taught to stimulate the inner self of man 
to awake from inertia and use his infinite potent energy by concentrating on a persistent omnipotent energy to realize the ultimate goal of birth. The complex process of rejuvenation through "Kaya Karpam" is the real elixir of life to maintain healthy life.

A theosophical aphorism in Tamil said by Saint Avvaiyar quoted that "Meley amirthathai vilangaa mattrannunil Kaalanai vanchik kalaam"- Avvaikural (67) which put up with Human being can delay the indicators of Narai-greying, Thirai-wrinkles, Moopu-aging, Pini-disease by conserving the body through realization, cherished mental strength, self-transcendence into immortal body particularly to achieve liberation in their lifetime which is the objective of human birth.[11] Equilibrium of three humor called vaatham-pitham-kapham is a key concept just as homeostasis, a pivotal concept within biology is linked with emotional regulation and physiological stability. The most significant framework of longevity is conserving best levels of vital hormones and other biochemical factors in our body.

\section{CONCLUSION}

Many perceptions of the Indian traditions share a belief in immortality and the locus of subtle body by our own natural self. In terms of economics, both psychological and physical illness definitely will reduce the overall productivity of the economy which result in poor standard of life and lowered earning potentials. Health and wealth are interrelated. Similarly, body and mind are also interrelated and mutually interdependent. Physical illness may lead to mental illness and vice versa. That is why we use to say that strong body will have strong mind. In fact, general health may be determined by various factors such as social, economic, environmental and behavioral factors of the individuals as well the society. The balance among the three dhosham namely vaatham, pitham and kapham may indicate the physical health of people. The absence of anxiety, anger, worry, jealous and stress may bring emotional balance in human being which in turn indicate mental health. Thus the complete physical and mental health may lead to a long healthy life.

\section{REFERENCES}

[1] A guide to Siddha medicine, National institute of Siddha, Ministry of AYUSH e-book.

[2] Central Bureau of Health Intelligence, Directorate General of Health Services. National health profile, New Delhi: Ministry of Health \& Family Welfare, Government of India.; 2018.

[3] Helliwell, J., Layard, R., \& Sachs, J, World Happiness Report, New York: Sustainable Development Solutions Network, 2019

[4] Laura D Kubzansky, Ichiro Kawachi, Going to the heart of the matter: do negative emotions cause coronary heart disease? Journal of Psychosomatic Research, Volume 48, Issues 4-5, 2000, P. 323-337.

[5] Hirve S, Juvekar S, Gambhudas S et al. Does self-rated health predict death in adults aged 50 years and above in India? Evidence from a rural population under health and demographic surveillance. Int J Epidemiol 2012; 41: 1719-27.

[6] Kiecolt et al.,Emotions, morbidity, and mortality: new perspectives from psycho neuroimmunology. Annual review of psychology. 53.83107.10.1146/annurev.psych. 53.100901.135217, 2002 
[7] Martin, Peter; MacDonald, Maurice; Margrett, Jennifer A.; and Poon, Leonard W., "Resilience and longevity: expert survivorship of centenarians" Human Development and Family Studies Publications. 65, 2010

[8] Scheier, Michael \& Carver, Charles. (1992). Effects of optimism on psychological and physical well-being: Theoretical overview and empirical update. Cognitive Therapy and Research. 16. 201-228. 10.1007/BF01173489.

[9] D. A. Revicki and J. P. Mitchell, "Strain, social support, and mental health in rural elderly individuals," Journals of Gerontology, vol. 45, no. 6, pp. S267-S274, 1990.

[10] Geetha A. Tamil Siddha Yoga Philosophy on Conception- Garba Kriya from Thirumoolar's Thirumandiram. J Yoga \& Physio. 2018; 4(1): 555626. doi: 10.19080/JYP.2018.04.555626.

[11] Saint Avvaiyar, Avvaiyar Arul Seitha Kuralmoolam ,Pubished by Chidambaram A.Rathinasabaapathi Mudaliyar, Chennai, 1943

[12] N. Kamakshi Priya and Dr. M. Kalyana Sundaram, a Study on Relationship between HRM Practices, Employee Wellbeing and Performance in the Selected Private Hospitals in Tiruchirappalli. International Journal of Management, 7(3), 2016, pp. 63-78.

[13] Dr. K. Devaraju, Correlations of Selected Psychological Variables Among College Level Football Players, International Journal of Advanced Research in Management (IJARM), Volume 5, Issue 6, November-December (2014), pp. 01-03

[14] K. Gunasekaran and Dr. S. Kamal, Identification of Work RelatedPsychological Health Behaviour Factors Affecting Among the Construction Workers Health and Work Progress. International Journal of Advanced Research in Engineering and Technology, 9(5), 2018, pp $11-22$.

[15] M. Priyadarshini and Dr. B. Sripirabaa, Influence of Organizational Politics on Psychological Capital, Journal of Management, 5(6), 2018, pp. 47-57. 